\title{
Effect of Co-B Catalyst Synthesized in Methanol on the Hydrolysis of Sodium Borohydride
}

\author{
Mehmet Sait İZGİ ${ }^{1}$, Ömer SAHINN ${ }^{1}$, Erhan ONAT, ${ }^{2}$ Sabit HOROZ ${ }^{3}$
}

\begin{abstract}
In this study, the effect of parameters such as treatment time, temperature, amount of catalyst and the $\mathrm{NaBH}_{4}$ concentration were investigated on the catalytic activity of Co-B catalyst synthesized in methanol and the optimum conditions were determined. The maximum hydrogen generation rate was found as $2200 \mathrm{mLH}_{2} /$ min.g.catalyst for Co-B catalyst synthesized in methanol while $600 \mathrm{mLH}_{2} / \mathrm{min}$.g.catalyst was found for Co-B catalyst synthesized in water. The activation energy was found as $34.694 \mathrm{~kJ} / \mathrm{mol}$ for Co- B catalyst prepared in methanol. Consequently, our results suggest that the cold plasma treatment with different conditions can be used as a promising technique to enhance the catalytic activity of Co-B catalyst prepared in the methanol.
\end{abstract}

Keywords: Co-B catalyst, cold plasma treatment, methanol, sodium borohydride.

\section{Metanolde Sentezlenen Co-B Katalizörün Sodyum Hidrolizi Üzerine Etkisi}

ÖZET: Bu çalışmada, metanol içinde sentezlenen Co-B katalizörünün etkinliğini arttırmak için alternatif bir yöntem olarak soğuk bir plazma yöntemi seçilmiştir. Işlem süresi, sıcaklık, katalizör miktarı ve $\mathbf{N a B H}_{4}$ konsantrasyonları gibi parametrelerin Co-B katalizörün katalitik aktivitesi üzerindeki etkisi araştırılmış ve optimum koşullar belirlenmiştir. Maksimum hidrojen üretim oranı, metanolde sentezlenen Co-B katalizörü için $2200 \mathrm{mLH}_{2} /$ min.g.katalizör olarak bulunurken, suda sentezlenen Co-B katalizörü için $600 \mathrm{mLH}_{2} / \mathrm{min}$.g. katalizör olarak bulunmuştur. Metanolde hazırlanan Co-B katalizörü için aktivasyon enerjisi $34.694 \mathrm{~kJ} / \mathrm{mol}$ olarak belirlenmiş̧ir. Sonuç olarak, sonuçlarımız, farklı koşullardaki soğuk plazma işleminin, metanolde hazırlanan Co-B katalizörünün katalitik aktivitesini arttırmak için umut verici bir teknik olarak kullanılabileceğini göstermektedir.

Anahtar Kelimeler: Co-B katalizörü, soğuk plazma işlemi, methanol, sodyum borhidrür.

\footnotetext{
Mehmet Sait İZGİ (0000-0003-3685-3219), Ömer ŞAHİN (0000-0003-4575-3762), Siirt Üniversitesi, Mühendislik Mimarlık Fakültesi, Kimya Mühendisliği, Siirt, Türkiye

Erhan ONAT (0000-0003-1638-0151), Bitlis Eren Üniversitesi, Fen Bilimleri Enstitüsü, Kimya Bölümü, Bitlis, Türkiye

3 Sabit HOROZ (0000-0002-3238-8789), Siirt Üniversitesi, Fen Edebiyat Fakültesi, Fizik Bölümü, Siirt, Türkiye
}

Sorumlu yazar/Corresponding Author: Mehmet Sait IZGİ, saitizgi@hotmail.com 


\section{INTRODUCTION}

Hydrogen can be produced using a wide variety of techniques without the emission of pollutants and greenhouse gases, and as technology improves, production costs are targeted to reach levels comparable to other sources. Nowadays, hydrogen is produced by catalytic conversion from natural gas or hydrolysis of water. However, these methods are not fast enough and flexible for portable PEM fuel cells. For this reason, small-scale hydrogen generator systems, which can quickly supply pure hydrogen, are gaining importance (Fakeeha et al., 2016,; Ismaev et al., 2016; Izgi et al., 2017; Gupta et al., 2005; Balat, 2008; Niwa et al., 2012).

Chemical hydrides which are stable, non- combustible, and non-toxic in nature, have $10.8 \%$ of hdyrogen storage capacity (Sahin et al., 2015; Liang et al., 2008; Qiming et al., 2012). Sodium borohydride $\left(\mathrm{NaBH}_{4}\right)$ is one of these chemical hydrides. The hydrolysis of $\mathrm{NaBH}_{4}$ with water was shown by Schlesinger et al (Schlesinger et al., 1953).

Heterogeneous and homogeneous catalysts such as $\mathrm{Ni}$ (Ingersoll et al., 2007), Co (Fernandes et al, 2009), Co-B (Izgi, 2015), Co-B-Cr (Izgi et al., 2015), Co-Cu-B (Izgi et al., 2016), Co-B-P (Sahin et al., 2016) and CoB-F (Cho et al., 2007) were used to carry out the process of $\mathrm{NaBH}_{4}$. Unlike the homogeneous catalysts, the heterogeneous catalysts have some advantages such as longer operation of catalyst, easy separation of catalyst from the sodium meta-borate $\left(\mathrm{NaBO}_{2}\right)$ solution, and there is no formation of other byproducts apart from $\mathrm{NaBO}_{2}$ during the process (Fakeeha et al, 2016; Saka et al., 2015; Benitez et al, 1997; Isha et al., 2012;). Among these catalysts, the Co-B is a good candidate for hydrogen generation owing to its high activity and low cost (Krishann et al., 2009; Ozdemir et al., 2013; Coskuner et al., 2014).

Generally, the water has been used as solvolytic agent for generation hydrogen from the hydrolysis of $\mathrm{NaBH}_{4}$. However, during past decades, some reports showed that methanol can be used as solvolytic solvent as an alternative to the use of water (Schlesigner et al., 1953; Fernandes et al., 2009; Ocon et al., 2013; Kim et al., 2004).
In our present study, the methanol was used as solvolytic agent for generation hydrogen from the hydrolysis of $\mathrm{NaBH}_{4}$ for the first time. Before the cold plasma treatment was applied, $10 \%$ of $\mathrm{NaOH}$ concentration was determined as the most efficient concentration of $\mathrm{NaOH}$ on the $\mathrm{NaBH}_{4}$ hydrolysis of the Co-B catalyst synthesized in the methanolic medium. The effect of parameters such as treatment time, temperature, amount of catalyst and the $\mathrm{NaBH}_{4}$ concentration were investigated on the catalytic activity of Co-B catalyst and the optimum conditions were determined. The Co-B catalyst was characterized by XRD, SEM, BET and FTIR measurements. Consequently, the results suggest that the methanol can be used as an alternative solvent to increase the activity of Co-B catalyst.

\section{EXPERIMENTAL DETAILS}

\section{Preparation}

The chemical reduction method was used to synthesize Co-B catalyst for production of hydrogen from sodium borohydride solutions. $\mathrm{CoCl}_{2} \cdot 6 \mathrm{H}_{2} \mathrm{O}$ as Co source and $\mathrm{NaBH}_{4}$ as B source were utilized for preparation of Co-B catalyst in the methanol. In typical the chemical reduction method; After about $1.25 \mathrm{~g}$ of $\mathrm{CoCl}_{2} \cdot 6 \mathrm{H}_{2} \mathrm{O}$ was dissolved in $50 \mathrm{~mL}$ of methanol, this solution, which was placed in a 250 $\mathrm{mL}$ three-necked balloon, was cooled to about 2-4 ${ }^{0} \mathrm{C}$ and $1.25 \mathrm{~g}$ of sodium borohydride dissolved in methanol was slowly added drop wise with vigorous stirring. Once a black precipitate was obtained, it was washed several times with absolute ethanol to remove foreign substances in the precipitate. The final product was dried in $\mathrm{N}_{2}$ at $110{ }^{\circ} \mathrm{C}$ for 8 hours to obtain Co-B catalyst.

The cold plasma treatment was applied on the Co-B catalyst after the synthesis process was completed. The effect of parameters such as treatment time $(0,10 \mathrm{~min}, 20 \mathrm{~min}$, and $30 \mathrm{~min})$, temperature $\left(30{ }^{\circ} \mathrm{C}, 40{ }^{\circ} \mathrm{C}, 50{ }^{\circ} \mathrm{C}\right.$ and $\left.60{ }^{\circ} \mathrm{C}\right)$, and amount of catalyst $(0.0125 \mathrm{~g}, 0.025 \mathrm{~g}, 0.05 \mathrm{~g}, 0.75 \mathrm{~g}, 0.25 \mathrm{~g})$ were investigated on the catalytic activity of Co-B catalyst and the optimum conditions were determined. 


\section{Characterization}

X-ray diffraction (XRD on a Bruker D8 Advance $\mathrm{X}$-ray diffractometer with $\mathrm{Cu} \mathrm{K} \alpha$ source and scanning electron microscope (SEM) (JEOL JSM 5800) were used to analyze structural and morphological properties, respectively. The porous properties of catalyst were examined using $\mathrm{N}_{2}$ adsorp-

\section{RESULT AND DISCUSSIONS}

\section{Effect of Solvent Type}

In this study, methanol and water were used as the reducing medium for the Co-B catalyst. The reason of using different solvents is to see how tion studies. The measurements were carried out on Micromeritics ASAP 2000 with adsorptive and desorptive apparatus and the Co-B catalyst were pretreated in vacuum at $350{ }^{\circ} \mathrm{C}$ for $20 \mathrm{~h}$ before the measurements. The surface area was calculated from the isotherms using the Brunauere Emmette Teller (BET) equation.

different solvent environments affect the catalytic activity and particle size of the catalyst. The time-dependent change in hydrogen gas volumes obtained using these catalysts in the hydrolysis of $\mathrm{NaBH}_{4}$ catalysts is given in Figure 1 .

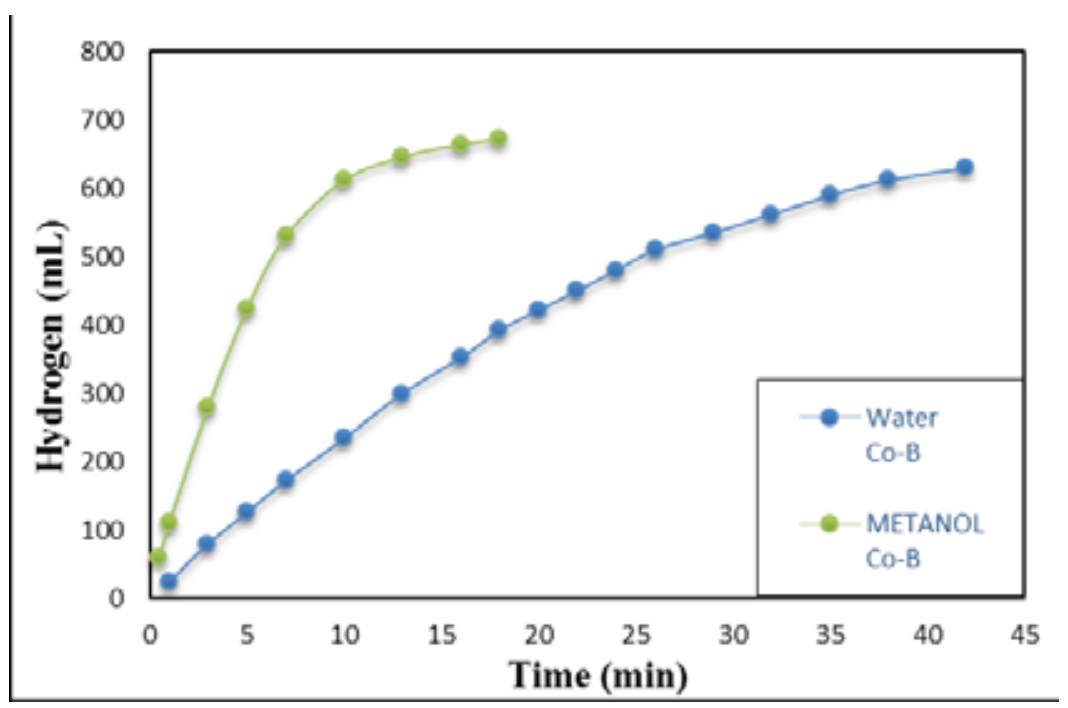

Figure 1 The effect of solvent type on the hydrolysis of $\mathrm{NaBH}_{4}$ with Co-B catalyst synthesized in different solvents (NaOH concentration: $10 \%$, catalyst amount: $25 \mathrm{mg}, \mathrm{NaBH}_{4}$ concentration: $2.5 \%$, reaction temperature: $30^{\circ} \mathrm{C}$ ).

As can be seen in Figure 1, when methanol was used as the reducing medium of the reaction catalyst, the reaction was completed in 20 minutes with the same temperature and amount of catalyst while water was used as the solvent, the hydrolysis with the catalyst obtained was completed in 40 minutes. Thus, it has been determined that the most effective catalyst for the hydrolysis of $\mathrm{NaBH}_{4}$ is the Co-B catalyst synthesized in the methanol environment.

\section{Effect of $\mathrm{NaOH}$ Concentration}

Since $\mathrm{NaBH}_{4}$ spontaneously degrades, $\mathrm{NaOH}$ should be used to stabilize the environment. In this regard, $\mathrm{NaOH}$ was used at different concentrations in the initial environment of hydrolysis to provide stability of the $\mathrm{NaBH}_{4}$. The most effective $\mathrm{NaOH}$ concentration on the $\mathrm{NaBH}_{4}$ hydrolysis of the Co-B catalyst synthesized in the methanolic medium was determined to be $10 \%$ as shown in Figure 2. 


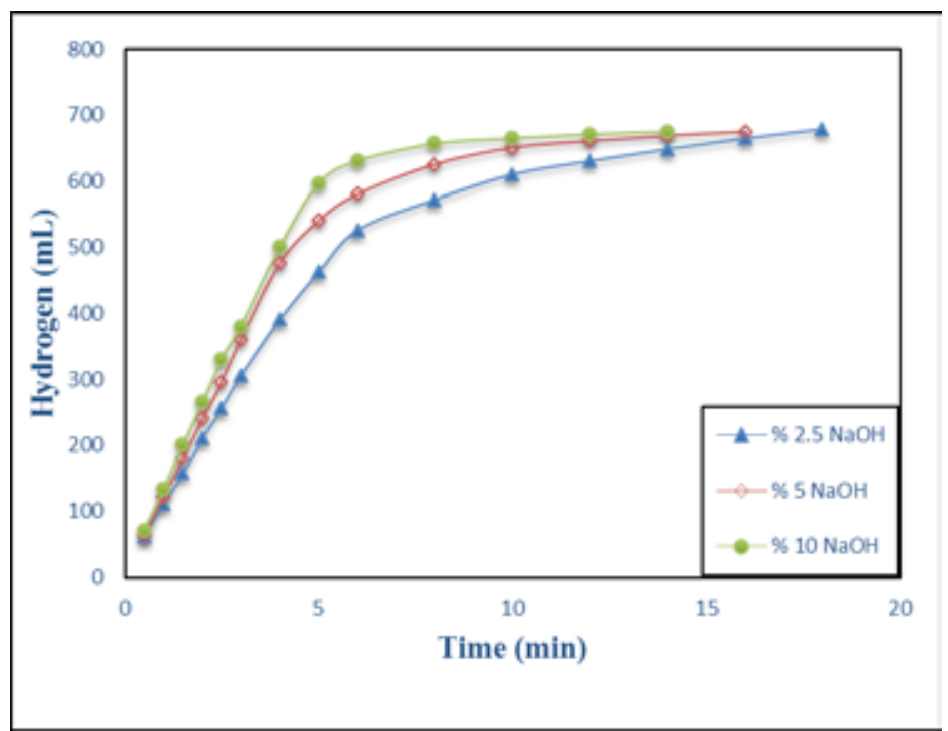

Figure 2 Effect of Co-B catalyst synthesized in methanol in $\mathrm{NaBH}_{4}$ hydrolysis at different $\mathrm{NaOH}$ concentrations $\left(30{ }^{\circ} \mathrm{C}, 2.5 \% \mathrm{NaBH}_{4}\right.$, $25 \mathrm{mg}$ of catalyst, $10 \mathrm{~mL}$ of solution).

\section{Effect of different amounts of Co-B catalyst}

The data for experiments in which the effect of different amounts of catalyst (12.5-75 mg) on the hydrolysis of $\mathrm{NaBH}_{4}$ was examined with the Co-B catalyst synthesized in the methanolic medium being the same as the variables used in previous experiments $(\mathrm{NaOH}$ concentration, $\mathrm{NaBH}_{4}$ percentage, temperature, solution volume) are given in Figure 3.

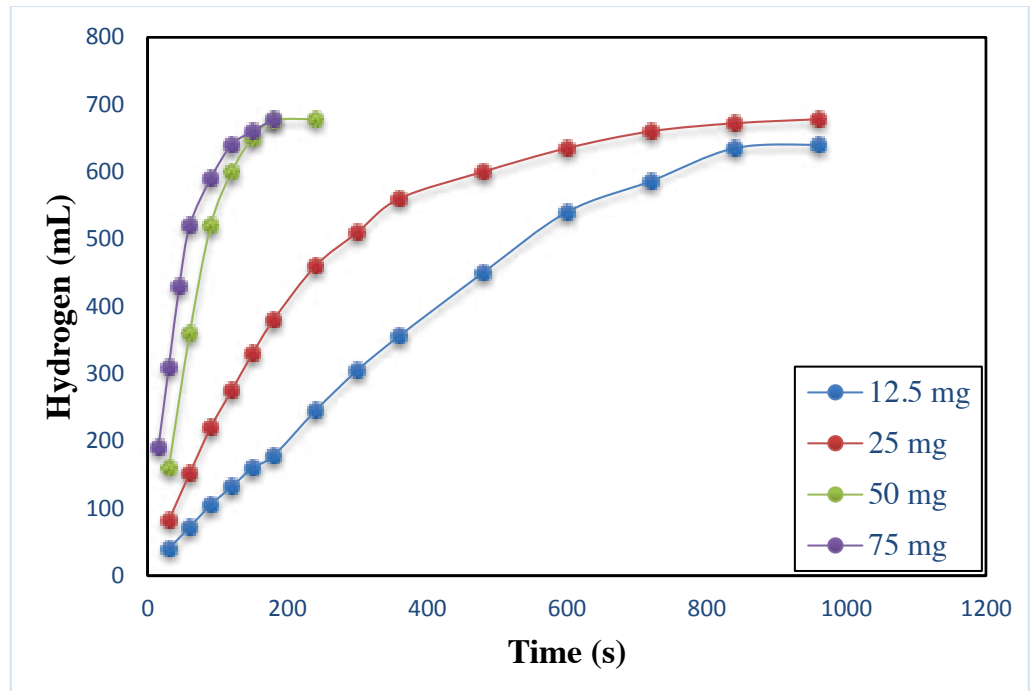

Figure 3 Effect of different catalyst amounts of $\mathrm{Co}-\mathrm{B}$ catalyst synthesized in methanol on $\mathrm{NaBH}_{4}$ hydrolysis $\left(30{ }^{\circ} \mathrm{C}, 2.5 \% \mathrm{NaBH}_{4}, 10 \%\right.$ $\mathrm{NaOH}, 10 \mathrm{~mL}$ solution).

As shown in Figure 3, hydrolysis of the $\mathrm{NaBH}_{4}$ completed in a shorter time with the increasing amount of catalyst. It can be explained that there is no connection between the amount of catalyst and the rate of hydrogen production. It can be said that only the amount of $\mathrm{NaBH}_{4}$ per unit catalyst is caused by the reduction in the $\mathrm{NaBH}_{4}$ concentration, depending on the amount of catalyst that is increasing; This depends on the increasing amount of catalyst.

\section{Effect of $\mathrm{NaBH}_{4}$ Concentration}

Figure 4 demonstrates effect of $\mathrm{NaBH}_{4}$ concentration on the hydrolysis of $\mathrm{NaBH}_{4}$ 


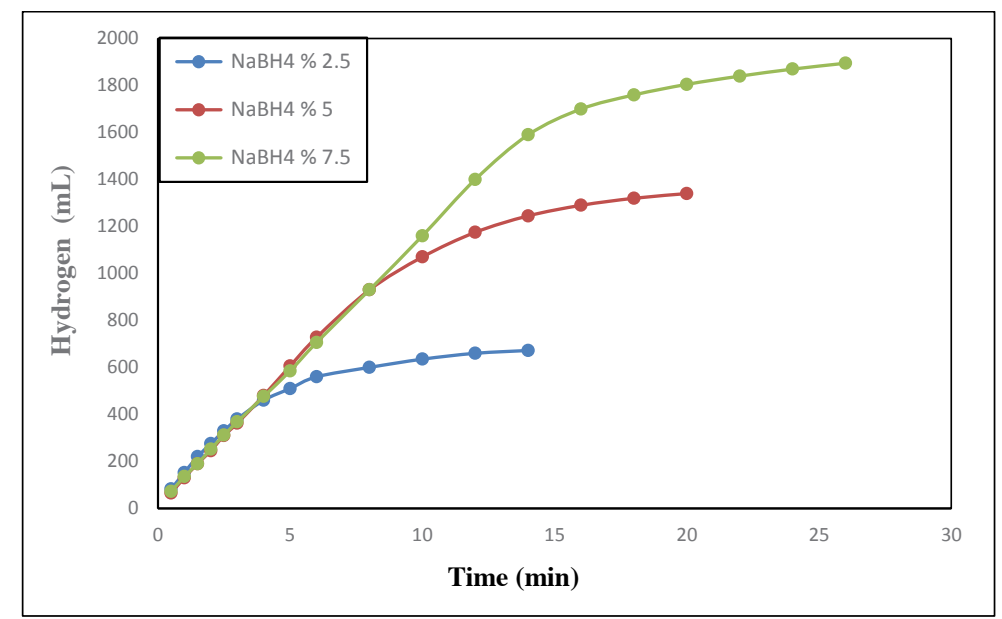

Figure 4 Effect of sodium borohydride concentrations on $\mathrm{NaBH}_{4}$ hydrolysis with Co-B catalyst synthesized in methanol ( $\mathrm{NaOH}$ concentration: $10 \%$, catalyst amount: $25 \mathrm{mg}$, reaction temperature: $30{ }^{\circ} \mathrm{C}$ ).

As the $\mathrm{NaBH}_{4}$ concentration rises, the rate of hydrogen production steadily increases. The possible reason for this is related to the hydrogen content in $\mathrm{NaBH}_{4}$. With increasing $\mathrm{NaBH}_{4}$ concentration, the hydrogen content is rised and accordingly the hydrogen production rate is increased.

Hydrogen production at different $\mathrm{NaBH}_{4}$ concentration confirms this interpretation. Because the rate of hydrogen production at $2.5 \% \mathrm{NaBH}_{4}$ concentration was $1920 \mathrm{mLH}_{2} / \mathrm{min}$.g.catalyst while the rate of hydrogen production at $7.5 \%$ concentration was $3116 \mathrm{mLH}_{2} /$ min.g.catalyst.

\section{Effect of Reaction Temperature"}

As can be seen in Figure 5, the $\mathrm{NaBH}_{4}$ hydrolysis reaction rate of the Co-B catalyst at different temperatures increases as the temperature of the solution medium increases with the same amount of catalyst and the same $\mathrm{NaBH}_{4}$ concentration. It was observed that the change of the hydrogen gas volume with time is not linear at different temperatures.

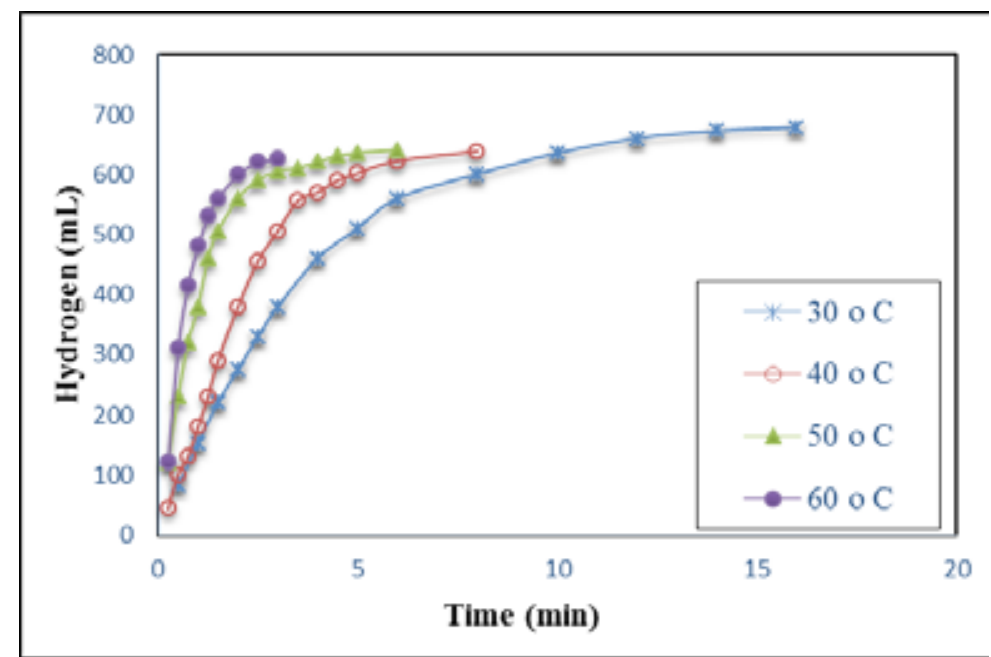

Figure 5 Effect of temperatures on hydrolysis of $\mathrm{NaBH}_{4}$ with Co-B catalyst synthesized in methanolic medium (NaOH concentration: $10 \%$, catalyst amount: $25 \mathrm{mg}, \mathrm{NaBH}_{4}$ concentration: $2.5 \%$ ).

The degree of reaction was determined by applying the first-order kinetic model to the effect of the behavi- or of the Co-B catalyst synthesized in the methanolic medium on $\mathrm{NaBH}_{4}$ hydrolysis. 


$$
-r_{N a B H 4}=-\frac{d C_{N a B H 4}}{d t}=k C_{N a B H 4}
$$

If the Equation 1 was integrated, the rate of hydrogen production shown in Equation 2 was obtained.

$$
\ln \left(\frac{C_{N a B H 4(t=0)}}{C_{N a B H 4(t=t)}}\right)=k t
$$

Kinetic evaluation was performed for $30^{\circ} \mathrm{C}, 40$ ${ }^{\circ} \mathrm{C}, 50^{\circ} \mathrm{C}$ and $60{ }^{\circ} \mathrm{C}$ using the Equation 2. Figure 6 indicates the variation between concentrations of $\mathrm{NaBH}_{4}$ obtained at different temperatures and time and it was observed that the change is linear. This shows us how the values of the first order and the reaction rate constants are suitable.

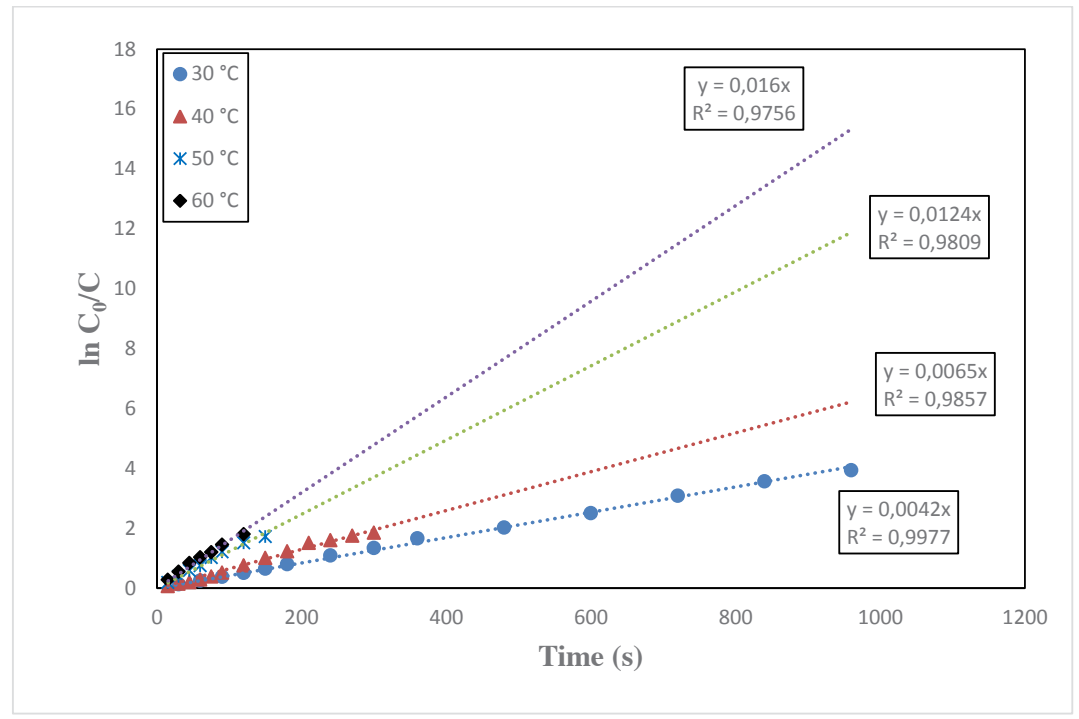

Figure 6 The first order reaction kinetics (10 mL solution, $2.5 \% \mathrm{NaBH}_{4}, 25 \mathrm{mg}$ catalyst, $\left.10 \% \mathrm{NaOH}\right)$ of Co-B catalyst synthesized in the methanolic medium.

Using the reaction rate constants obtained at different temperatures, the Arrhenius equation was deter- mined using Equations 3 and 4 to find the activation energy for the hydrolysis reaction.

$$
k=A \cdot e^{-E a}
$$

If both sides $(\ln )$ are taken in order to linearize Equation 3

$$
\ln k=\ln A-\frac{E a}{R T}
$$

When the $1 / \mathrm{T}$ graph was plotted against the ln $\mathrm{k}$ values according to Equation 4, the activation energy was found from the slope of the line obtained in Figure 7. According to these values obtained, the activation energy was determined as $34.694 \mathrm{~kJ} / \mathrm{mol}$. 
$\ln (\mathrm{k})$

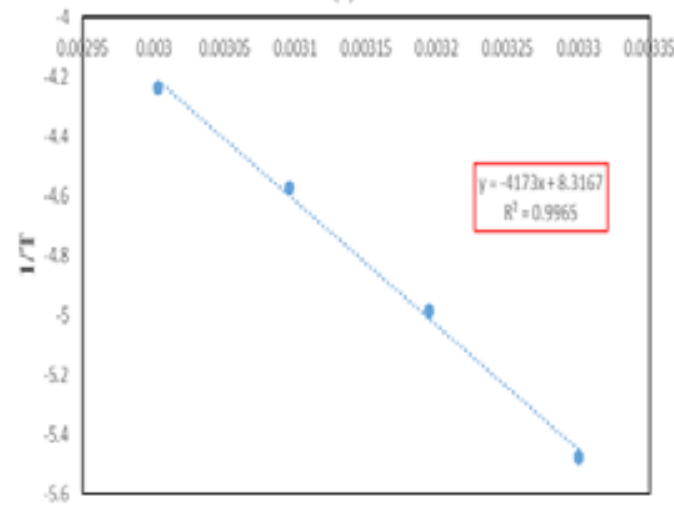

Figure 7 According to first order kinetic reaction, Arhenius equality for the Co-B catalyst synthesized in methanol.

\section{Characterization of Co-B catalyst synthesized in methanol and water environments}

The characterization of the Co-B catalyst synthesized in water and methanol mediums was determined by BET, SEM, XRD and FT-IR analyzes, respectively.

\section{BET characterization of Co-B catalyst}

As is known, one of the important parameters affecting catalyst activity and performance is the surface area of the catalyst. Physical adsorption and desorption analyzes of our synthesized catalysts were also carried out. Only BET surface areas are given from these obtained values. The BET surface area of the Co-B catalyst synthesized with purified water was $148.248 \mathrm{~m}^{2} / \mathrm{g}$ while the BET surface area synthesized in the methanol environment was $40.067 \mathrm{~m}^{2} / \mathrm{g}$. The micropores for the catalyst constitute an important part of the inner surface. Macropores are needed as a transmitter to ensure that the correct diffusion is faster than micropores. The obtained results are SEM shown in Figure 8.

\section{SEM characterization of Co-B catalyst}

Figure 8 shows SEM images of Co-B catalyst synthesized in pure water and methanol. Compared to SEM images, it is clear that the grain structure is reduced with methanol. At the same time, the catalyst synthesized with methanol turns into a more regular structure and reduces agglomeration, which prevents the crystallization of the catalyst.
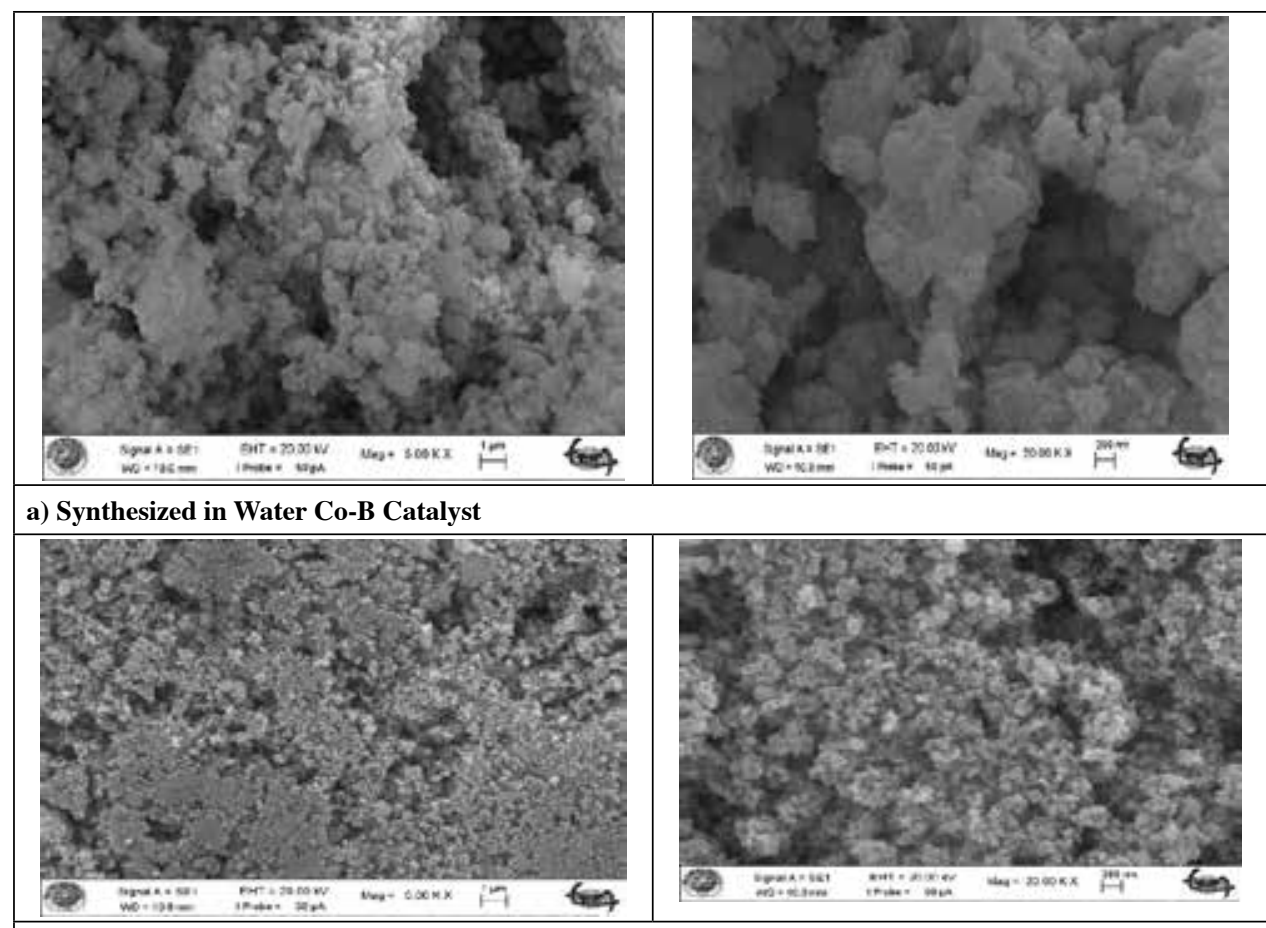

b) Synthesized in Methanol, Co-B Catalyst

Figure 8 SEM images (a) Co-B catalyst synthesized with pure water (b) Co-B catalyst synthesized with methanol. 


\section{XRD analysis of Co-B catalyst}

As shown in Figure 9, the Co-B catalyst synthesized in pure water or methanolic environment exhibits an amorphous structure in XRD analysis.

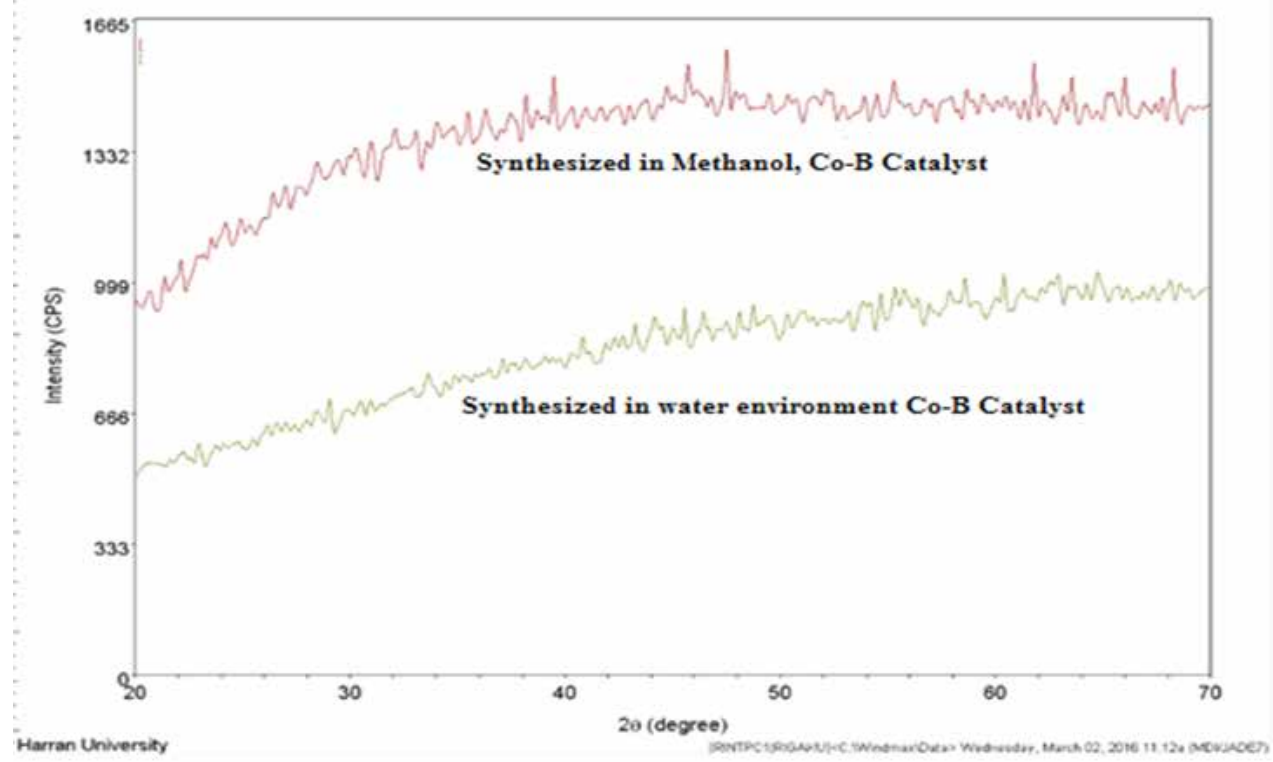

Figure 9 XRD of (a) Co-B catalyst synthesized with pure water (b) Co-B catalyst synthesized with methanol.

\section{FT-IR spectroscopy of Co-B catalyst}

Figure 10 indicates the FT-IR results for the Co-B catalyst. As seen in the figures, there is no structural change in the synthesis of Co-B catalyst in pure water and methanol environments. As a result, it can be conc- luded that when the the Co-B catalyst is synthesized with methanol in order to increase the catalytic activity of the Co-B catalyst, only the number of micro- and meso pores of the catalyst, which does not deteriorate its chemical structure, can be increased.

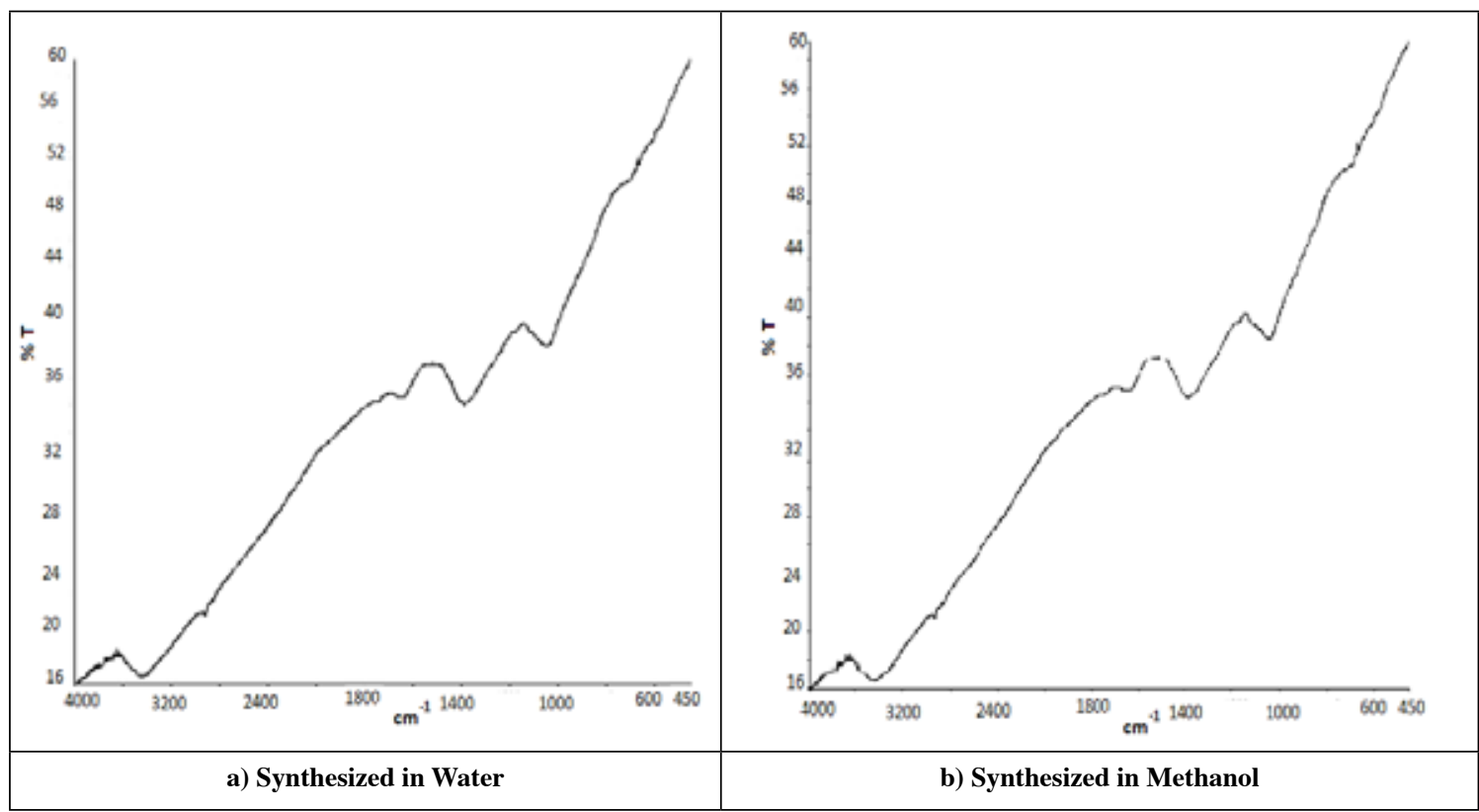

Figure 10 IR spectra of (a) Co-B catalyst synthesized with pure water (b) Co-B catalyst synthesized with methanol. 


\section{CONCLUSIONS}

Co-B catalyst was succesfully synthesized in water and methanol for generation hydrogen from the hydrolysis of $\mathrm{NaBH}_{4}$. The effect of solvolytic agent on the activity of Co-B catalyst was investigated and it was observed that the hydrogen production rate of hydrolysis reaction of $\mathrm{NaBH}_{4}$ with Co-B catalyst prepared in the methanol is completed in shorter time compare to one is syntheszied in the water. The cold plasma treatment was applied on the Co-B catalyst which was prepared in methanol solvent. Before the cold plasma treatment was applied, $10 \%$ of $\mathrm{NaOH}$ concentration was determined as the most efficient concentration of $\mathrm{NaOH}$ on the $\mathrm{NaBH}_{4}$ hydrolysis of the Co-B catalyst synthesized in the methanolic medium. The effect of parameters such as treatment time, temperature, amount of catalyst and the $\mathrm{NaBH}_{4}$ concentration were investigated on the catalytic activity of Co-B catalyst and the optimum

\section{REFERENCES}

Balat M. 2008. Possible Methods for Hydrogen Production. Energy Sources, Part A: Recovery, Utilization, and Environmental Effects. 31: 39-50.

Benitez P, Delgado A, Farrera JA, Ribó JM. 1997. Preparation of $\omega$-Hydroxy Acids by Reduction of $\alpha, \omega$-Methylene Diesters with NaBH4. Synthetic Communications. 27: 1697-1702.

Cho KW, Kwon HS. 2007. Effects of electrodeposited Co and CoeP catalysts on the hydrogen generation properties from hydrolysis of alkaline sodium borohydride solution. Catal. Today. 120: 298-304

Copkuner B, Kanturk, AF, Pipkin S. 2014. Sonochemical Approach to Synthesis of Co-B Catalysts and Hydrolysis of Alkaline NaBH4 Solutions. Journal of Chemistry. 185957.

İzgi MS, 2015. Effect of microwave irritated Co-B-Cr catalyst on the hydrolysis of sodium borohydride. Energy Sources Part A Recovery Utilization and Environmental Effects. 0562; 1-16.

İzgi MS, Odemis O, Sahin O. 2016. Co-B-F ve Co-B-P Katalizörleri Kullanilarak NaBH4' den Hidrojen Üretimine $\mathrm{NaOH}$ 'in Etkisi. SelçukÜniversitesiMühendislik, BilimveTeknoloji Dergisi. 4: 55-64.

İzgi MS, Pahin Ö, Ödemip Ö, Saka C. 2017. Microwave treatment and fluorine addition on Co-B catalyst to improve the hydrogen production rate. Materials and Manufacturing Processes. 1303159: 1-6.

İzgi MS, Pahin Ö, Saka C. 2015. Hydrogen production from NaBH4 using $\mathrm{Co}-\mathrm{Cu}-\mathrm{B}$ catalysts prepared in methanol: Effect of plasma treatment. Int. J. of Hydrogen Energy. 41: 1600-1608.

Fakeeha AH, Ibrahim AA, Khan WU, Abasaeed AE, Al-Fatesh AS. 2016. Hydrogen production by catalytic methane decomposition over $\mathrm{Ni}, \mathrm{Co}$, and $\mathrm{Ni}-\mathrm{Co} / \mathrm{Al} 2 \mathrm{O} 3$ catalyst. Petroleum Science and Technology. 34: 1617-1623. conditions were determined. The hdyrogen generation rate of Co-B catalyst synthesized in methanol is 2200 $\mathrm{mLH}_{2} /$ min.g.catalyst, while the value of the catalyst synthesized in pure water is $600 \mathrm{mLH}_{2} /$ min.g.catalyst. At the same time, the initial rates of these values at $t=$ 0 were $4635 \mathrm{mLH}_{2} / \mathrm{min}$.g.catalyst in methanol and the hydrogen production rate of Co-B catalyst in pure water was $1063 \mathrm{mLH}_{2} / \mathrm{min}$.g.catalyst at $\mathrm{t}=0$. The activation energy was determined as $34.694 \mathrm{~kJ} / \mathrm{mol}$ for Co- B catalyst prepared in methanol. It can be concluded that the cold plasma treatment may be used in the hydrogen generation from hydrolysis of $\mathrm{NaBH}_{4}$ in the presence of Co-B catalyst prepared in methanol.

\section{Acknowledgment}

This study was supported by Scientific Research Projects Coordination Unit of Bitlis Eren University. Project No: BEBAP 2015.08.

Fakeeha, AH, Ibrahim AA, Khan WU, Abasaeed AE, Al-Fatesh AS, 2016. Hydrogen production by catalytic methane decomposition over $\mathrm{Ni}, \mathrm{Co}$, and $\mathrm{Ni}-\mathrm{Co} / \mathrm{Al} 2 \mathrm{O} 3$ catalyst. Petroleum Science and Technology. 34:1617-1623.

Fernandes R, Patel N, Miotello A. 2009. Hydrogen generation by hydrolysis of alkaline NaBH4 solution with Cr-promoted Co-B amorphous catalyst. Appl. Catal B Environ., 92: 68-74.

Fernandes R,. Pinto AMFR,. Rangel CM. 2009. Hydrogen production from sodium borohydride in methanol-water mixtures. International journal of hydrogen energy. 35: 98629868.

Gupta SS, Bandyopadhya NR, Datta J. 2005. Carbon-Supported Platinum Catalysts for Direct Alcohol Fuel Cell Anode. Materials and Manufacturing Processes. 21: 703-706.

Ingersoll JC, Mani N, Thenmozhiyal JC, Muthaiah A. 2007. Catalytic hydrolysis of sodium borohydride by a novel nickelcobalt-boride catalyst. Journal of Power Sources. 173: 450457.

Isha R, Williams PT. 2012. Hydrogen production from catalytic steam reforming of methane: influence of catalyst composition. Journal of the Energy Institute. 85: 29-37.

Ismaev TI, Safiullin RA, Strelnik ID, Musina EI, Kadirov MK, Karasik AA, Sinyashin OG. 2016. Nickel-organic complexes as catalyst in PEM fuel cells. Phosphorus, Sulfur, and Silicon and the Related Elements. 191: 1654-1655.

Kim JH, Lee H, Han SC, Kim HS, Song MS, Lee JY. 2004. Production of hydrogen from sodium borohydride in alkaline solution: development of catalyst with high performance. International Journal of Hydrogen Energy. 29: 263-267.

Krishnan P, Advani SG, Prasad AK. 2009. Thin-film CoB catalyst templates for the hydrolysis of $\mathrm{NaBH} 4$ solution for hydrogen generation. Applied Catalysis B: Environmental,. 86:137-144. 
Mehmet Sait İZGİ et al.

Liang J, Li Y, Huang Y, Yang Y, Tang H, Wei Z, Shen PK. 2008. Sodium borohydride hydrolysis on highly efficient $\mathrm{Co}-\mathrm{B} / \mathrm{Pd}$ catalysts. International Journal of Hydrogen Energy. 33: 40484054.

Niwa K, Tamura K, Anandan S, Ikuma Y. 2012. Hydrogen production using mesoporous titanium dioxide. Energy Materials: Materials Science and Engineering for Energy Systems. 7: 34-38.

Ocon JD, Tuan TN, Yi Y, Leon RL, Lee JK, Lee J. 2013. Ultrafast and stable hydrogen generation from sodium borohydride in methanol and water over Fe-B nanoparticles. Journal of Power Sources. 243: 444-450.

Ozdemir, OK, Hasimoglu A, Ahsen AS. 2013. Synthesis of graphene-based Co-B catalyst via simultaneous chemical reduction for hydrolysis of sodium borohydride. Journal of Renewable and Sustainable Energy. 5: 063135.

Peng S, Fan X, Wu Y, Zhang J. 2013. Kinetic Study of Hydrogen Generation from the Hydrolysis of Alkaline NaBH4 over Ru/ MMT: an Insight on the Effect of Catalyst Amount. Integrated Ferroelectrics. 147: 159-165.
Qiming L, Kim H. 2012. Hydrogen production from NaBH4 hydrolysis via Co-ZIF-9 catalyst. Fuel Processing Technology. 100: 43-48

Sahin O, Karakas DE, Kaya M, Saka C. 2016. The effects of plasma treatment on electrochemical activity of Co-B-P catalyst for hydrogen production by hydrolysis of $\mathrm{NaBH} 4$. Journal of the Energy Institute. 90: 466-475.

Saka C, Sahin O, Demir H, Karabulut A, Sarikaya A. 2015. Hydrogen generation from sodium borohydride hydrolysis with a CueCo-based catalyst: a kinetic study. Energy Sources Part A. 37: 956- 964

Schlesigner IH, BrownC, Finholt AE, Gilbreath IR, Hoekstra HR, Hyde EK. 1953 Sodium borohydride, its hydrolysis and its use as a reducing agent and in the generation of hydrogen. Journal of the American Chemical Society. 75: 215-219.

Sahin Ö, Kaya M İzgi MS, Saka C. 2015. The effect of microwave irradiation on aCo-B-based catalyst for hydrogen generation by hydrolysis of NaBH4 solution. Energy Sources, Part A. 37: 462-467. 